\title{
Review \\ The Biology of Ocular Adnexal Marginal Zone Lymphomas
}

\author{
Patricia Johansson ${ }^{1, *(\mathbb{D})}$, Anja Eckstein ${ }^{2}$ and Ralf Küppers ${ }^{1}(\mathbb{D}$ \\ 1 Institute of Cell Biology (Cancer Research), Faculty of Medicine, University of Duisburg-Essen, \\ 45147 Essen, Germany; ralf.kueppers@uk-essen.de \\ 2 Molecular Ophthalmology Group, Department of Ophthalmology, University of Duisburg-Essen, \\ 45147 Essen, Germany; anja.eckstein@uk-essen.de \\ * Correspondence: patricia.johansson@uk-essen.de; Tel.: +49-(0)201-723-3384
}

\section{check for}

updates

Citation: Johansson, P.; Eckstein, A.; Küppers, R. The Biology of Ocular Adnexal Marginal Zone Lymphomas. Cancers 2022, 14, 1264. https:// doi.org/10.3390/cancers14051264

Academic Editor: Markus Raderer

Received: 14 December 2021

Accepted: 23 February 2022

Published: 28 February 2022

Publisher's Note: MDPI stays neutral with regard to jurisdictional claims in published maps and institutional affiliations.

Copyright: (c) 2022 by the authors. Licensee MDPI, Basel, Switzerland. This article is an open access article distributed under the terms and conditions of the Creative Commons Attribution (CC BY) license (https:// creativecommons.org/licenses/by/ $4.0 /)$.
Simple Summary: Ocular adnexal marginal zone lymphoma (OAMZL) is a distinct type of lymphoma that presents in tissues around the eyeball. The lymphoma develops from mature B lymphocytes that have been triggered by antigens for prolonged times. It seems that the B cells often recognize autoantigens. The lymphoma cells often carry specific chromosomal gains and, in some cases, chromosomal translocations. A main factor in the development of this lymphoma is the constitutive activation of the NF- $\mathrm{kB}$ pathway, which occurs through various types of genetic alterations. Further key pathogenetic mechanisms involve epigenetic changes, indicated by recurrent mutations in epigenetic regulators.

\begin{abstract}
This review focuses on the biology of ocular adnexal marginal zone B-cell lymphomas of the mucosa-associated lymphatic tissue (MALT) (OAMZL) subtype. The ocular adnexa includes all structures and tissues within the orbit except for the eye bulb. In the region of the ocular adnexa, MALT lymphomas represent the most common subtype of lymphoma, accounting for around 8\% of all non-Hodgkin lymphomas. These lymphomas are often preceded by inflammatory precursor lesions. Either autoantigens or infectious antigens may lead to disease development by functioning as continuous antigenic triggers. This triggering leads to a constitutive activation of the NF- $\mathrm{kB}$ signaling pathway. The role of antigenic stimulation in the pathogenesis of OAMZL is supported by the detection of somatic mutations (partially with further intraclonal diversity) in their rearranged immunoglobulin V genes; hence, their derivation from germinal-center-experienced B cells, by a restricted IGHV gene usage, and the validation of autoreactivity of the antibodies in selected cases. In the established lymphomas, NF- $\mathrm{BB}$ activity is further enforced by mutations in various genes regulating NF- $\mathrm{KB}$ activity (e.g., TNFAIP3, MYD88), as well as recurrent chromosomal translocations affecting NF- $\mathrm{kB}$ pathway components in a subset of cases. Further pathogenetic mechanisms include mutations in genes of the NOTCH pathway, and of epigenetic regulators. While gene expression and sequencing studies are available, the role of differential methylation of lymphoma cells, the role of micro-RNAs, and the contribution of the microenvironment remain largely unexplored.
\end{abstract}

Keywords: ocular adnexal lymphoma; extranodal marginal zone lymphoma; mucosa-associated tissue; MALT lymphoma; NF-kB; ocular adnexa; orbit

\section{Definitions \\ 1.1. Ocular Adnexa}

Adjacent structures of the eye are called the ocular adnexa, which include the content of the orbit, the lacrimal apparatus, the extraocular muscles, the eyelids, the eyelashes, the eyebrows, and the conjunctiva. Most definitions of the orbit include extraocular muscles, blood vessels, nerves, fascia, and fat. The eyeball lying in the cavity is not part of the ocular adnexa. Details on anatomical structures can be found in relevant textbooks [1,2]. 


\subsection{Extranodal Marginal Zone Lymphomas}

Whereas most B-cell lymphomas primarily locate to the lymph nodes or other lymphoid organs, some lymphomas have a primary presentation in extranodal sites. The predominant form of such lymphomas is extranodal marginal-zone lymphoma (EMZL) [3]. The histological picture resembles marginal zones, the prototype of which is seen in the spleen, and marginal-zone B cells are indeed considered to be the normal counterpart of EMZL. Most EMZLs arise in mucosal tissues; hence, these lymphomas are then also defined as mucosa-associated lymphoid tissue (MALT) lymphomas. EMZL can occur at various locations in the body, including the stomach, the salivary glands, and the ocular adnexa. Ocular adnexal lymphomas (OALs) do not encompass lymphomas developing in the eyeball.

The majority of OALs are EMZLs of the MALT subtype developing in sites lacking germinal-center-containing lymphatic tissues. Primary OALs have to be distinguished from secondary lymphomas caused by involvement of the ocular adnexa with systemic lymphomas. Such systemic lymphomas involving the ocular adnexa are mostly diffuse large B-cell lymphomas, and will not be further considered here. In the following text, we will focus on the biology of ocular adnexal marginal zone lymphomas (OAMZLs). We refer to other recent reviews for clinical, diagnostic, and pathological aspects of OAMZL [4-7].

\section{Epidemiology}

In the orbit, OALs are the most common malignancy in adulthood, and account for $11 \%$ of all orbital masses. Primary OALs are nevertheless rare; they represent only $1-8 \%$ of all non-Hodgkin lymphomas [8-10], and $5-15 \%$ of all extranodal non-Hodgkin lymphomas [8]. The most common subtype of primary lymphoma of the ocular adnexa is extranodal marginal zone lymphoma of the MALT subtype, accounting for approximately $67-80 \%$ of cases [11,12]. Geographic differences have been recognized, with around $60 \%$ of OALs in the Western world being represented by OAMZLs, whereas in Asian case series approximately $80 \%$ of primary OALs are of this type $[5,9,11,13]$. The next most common lymphoma types in the ocular adnexa region are follicular lymphomas, mantle-cell lymphomas, and diffuse large B-cell lymphomas, each accounting for approximately $10 \%$ of primary OALs [11]. Other subtypes of B-cell lymphoma and T-cell lymphoma are very rare in this location. Overall, primary EMZL accounts for up to $74 \%$ of all orbital malignancies.

OALs show different frequencies for their sites of involvement. Primary conjunctival and eyelid lymphomas are reported in $20-33 \%$ and $5-24 \%$ of OALs, respectively $[6,14,15]$; the lacrimal drainage apparatus is rarely involved. For the lacrimal gland, the annual incidence is about $0.7 /$ million individuals; $99 \%$ of lymphomas in this location are B-cell lymphomas, with $68 \%$ of them EMZLs. The lacrimal sac is reported to be involved in $2 \%$ of patients $[16,17]$. Secondary involvement of the ocular adnexa with a systemic lymphoma is described in only $10-32 \%$ of all OAL cases [18].

From 1975 to 2001, the incidence of OAL has increased by 6.3\% annually, which is more rapidly than seen for other extranodal non-Hodgkin lymphomas $[19,20]$. A nationwide Danish study also reported a rising incidence of OAL from 1980 to 2017. This was observed for OAMZL for men and women, but not for follicular lymphoma, mantle-cell lymphoma, or diffuse large B-cell lymphoma [11]. The reasons for the rising incidence are not known. An increase in the annual incidence of OAMZL from 2001-2017 was also reported by Cerhan et al. for the USA [21].

\section{Morphology and Immunophenotype}

Morphologically, OAMZL is characterized by an infiltrate with expansion of the marginal zone surrounding residual germinal centers, if recognizable. The infiltrate consists of a heterogeneous population of small, round-shaped lymphocytes, including centrocytelike cells, monocytoid cells, and/or scattered immunoblasts (Figure 1) [22]. Plasmacytic differentiation is frequently seen. The plasmacytic cells express plasma cell markers only 
in $11 \%$ of cases [23]. The occurrence of these cells is not significantly associated with recurrence, systemic disease, or lymphoma-related death [23]

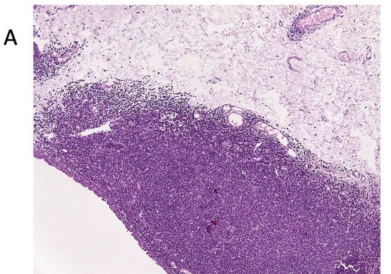

HE $\times 100$

D

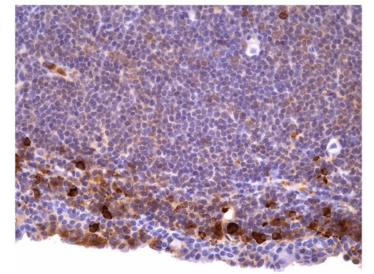

kappa $\times 400$

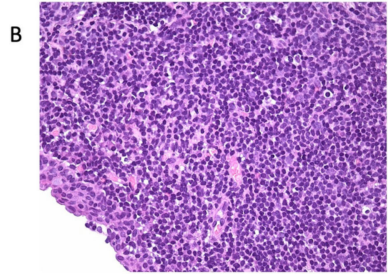

HE $\times 400$

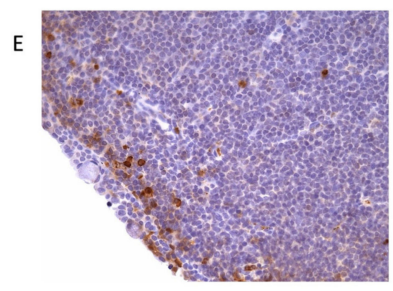

lambda $\times 400$

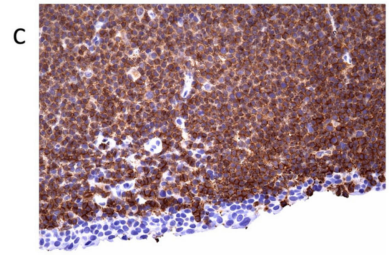

CD20 $\times 400$

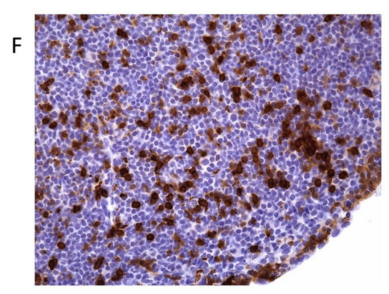

CD5 $\times 400$

Figure 1. Histology and immunophenotype of OAMZL: (A) immunohistochemistry (Hematoxylin and Eosin, H\&E staining) of conjunctival lymphoma; (B) enlarged view of an H\&E staining, demonstrating a dense infiltrate of small, round-shaped cells; (C) the lymphoma cells express CD20; $(\mathbf{D}, \mathbf{E})$ in this case, no clear overexpression of one light chain is observed; (F) CD5 staining. Tumor cells are negative; the intermingled $\mathrm{CD}^{+}$cells represent $\mathrm{T}$ cells.

Regarding the immunophenotype, OAMZL exhibits the same phenotype as other MALT lymphomas. For identification of a MALT lymphoma, no typical aberrant immunophenotypic markers are available. The cells express CD20, CD79a, PAX5, IgM, BCL2, and TCL1; several cases also express CD11c, CD43, and CD35; rare cases express CD5. The OAMZL cells are negative for IgD, CD3, CD10, CD23, cyclin D1, BCL6, and IRF4. The negativity for CD10, CD23, cyclin D1, and BCL6 can be helpful in the differential diagnosis of OAMZL versus small lymphocytic lymphoma $\left(\mathrm{CD} 23^{+}\right)$, mantle-cell lymphoma (cyclin $\left.\mathrm{D}^{+}\right)$, and follicular lymphoma $\left(\mathrm{CD} 10^{+} \mathrm{BCL}^{+}\right)$[3]. The immunophenotype of OAMZL lymphoma cells is therefore very similar to that of normal marginal-zone B cells. Light-chain restriction as an indication of monoclonality is not regularly detectable [24]. An example is given in Figure 1.

\section{Bilateral and Recurrent Disease}

Lymphomas diagnosed as primary OAMZL can arise bilaterally, either simultaneously or sequentially. Relapses can occur in nearly the same position, usually not in localizations previously irradiated, or can be found on the other eye. In rare cases, systemic relapses occur. The time between first manifestation and relapse can take more than a decade. Based on IGHV clonality analyses, Matsuo et al. observed that bilateral, recurrent, or systemically multifocal lesions represent a common clone [25].

Interestingly, the type of ocular adnexal and systemic lymphoma occurring in one patient can be different. In an analysis of 209 OAL patients-31\% of them presenting with a history of systemic lymphoma-the histological subtype was the same in $83 \%$ [26]. In $12.3 \%$ of patients, the OAL was more indolent than the systemic lymphoma. Several explanations are possible, e.g., transformation, composite lymphomas, or trafficking of cells to tissues encountering different microenvironmental settings. The mechanisms behind this are not yet well investigated. The observation of different lymphoma subtypes underscores the importance of biopsies for determination of the histological subtype, even in the context of systemic lymphoma [26]. 


\section{Etiology and Pathogenesis}

\subsection{Precursor Lesions}

Several precursor lesions potentially developing to OAMZL have been described, among them orbital pseudotumors (idiopathic orbital inflammatory disease (IOID)), reactive lymphoid hyperplasia (RLH), and IgG4-related disease [27]. Both exogenous antigens and autoantigens can trigger the abovementioned precursor lesions in the ocular adnexa. Precursor lesions as inflammatory non-malignant states have in common that they result in chronic antigenic stimulation, which may lead to activation of the NF- $\mathrm{kB}$ signaling pathway, to chromosomal alterations, and to other genetic and epigenetic alterations. This multistep process can drive lymphoma development [28].

OAMZL arising in the context of IgG4-related disease has been repeatedly reported as OAMZL with IgG4-positive cells or infiltrated by IgG4-positive cells [29-33]. In some cases, the differentiation between the two entities is challenging, since OAMZL exhibits IgG4positive plasma cells in up to $62 \%$ of cases [34]. Histopathologically, obliteration of venous vessels is specific. Plasma cells in IgG4-related disease are polytypic. In IgG4-related disease, eosinophilia, high IgE titers, polyclonal hypergammaglobulinemia, and often elevated serum IgG4 levels are observed [35]. Infraorbital nerve enlargement is a unique feature on MRI scans [31]. Upregulation of activation-induced cytidine deaminase (AID)—-the master factor for somatic hypermutation and class-switch recombination of immunoglobulin genes-was observed in IgG4-related ophthalmic disease and OAMZL, whereas AID expression was lower in IgG4-negative OAMZL [36]. AID might be a driver for oncogenesis in the development of IgG4-related ophthalmic disease to IgG4-positive OAMZL.

\subsection{Antigen Stimulation}

Chronic (auto)antigenic stimulation via chronic inflammation, infection, or autoimmune disease is supposed to be a relevant pathogenic mechanism in the development of primary MALT lymphoma in general [37]. A multistep process is supposed to promote survival and growth advantages of stimulated B cells, which may finally give rise to monoclonal B-cell populations. Various mechanisms are described causing this antigenic stimulation.

\subsubsection{Infectious Agents \\ Chlamydophila psittaci}

Chlamydia are human pathogenic intracellular bacteria that are typically transmitted via infected birds. Mostly, infections are asymptomatic, but they can cause pneumonia, chronic conjunctivitis, pericarditis, and hepatitis [38]. Chlamydophila psittaci can induce immune reactions cross-reacting with autoantigens, leading to insufficient elimination of the pathogen and induction of lymphoma development $[7,39,40]$.

The prevalence of $C$. psittaci in OAL seems to be region-specific. In most studies involving patients from Italy or Korea, C. psittaci was repeatedly detected by PCR and other methods in OAL cases. Other Chlamydia species were predominantly observed in China (C. pneumonia) and the UK (C. trachomatis) [7,41,42]. In other countries, however-including Japan, the USA, Cuba, the UK, the Netherlands, France, and Germany-no evidence for C. psittaci in samples of OAL was observed [43-51].

\section{(1) Other Bacteria}

Among 308 OAL patients analyzed in 11 studies, Helicobacter pylori was detected in $23 \%$ of the lymphomas [52]. However, there is the risk of contamination of OAL biopsy specimens by the rather prevalent $H$. pylori during sampling, so the true incidence may be substantially lower. Notably, the prevalence of OAL patients with H. pylori-positive gastric infections is overall no higher than in the general population [52], arguing against a significantly increased risk of OAL development in individuals with chronic gastric $H$. pylori infection. A recent study confirmed a lack of association between gastric $H$. pylori infection and OAL incidence [53]; none of 18 OAL cases in that study showed H. pylori 
DNA in the lymphoma tissue. Thus, the role of H. pylori in the development of OAL is still unresolved.

\section{(2) Viral Pathogens}

In several studies on a potential viral etiology of OAL, no viruses were detected in the lymphomas [51,54]. For chronic hepatitis $\mathrm{C}$ virus (HCV) infections, the association with marginal-zone lymphomas is especially well known $[55,56]$. Although there are clear indications for a role of $\mathrm{HCV}$ in the pathogenesis of some types of B-cell lymphoma, its role in OAMZL is less clear [57].

For human-immunodeficiency-virus-infected patients, a higher risk of developing marginal-zone lymphomas has been described, but there are no reports on higher incidences of OAMZL [58]. Regarding Epstein-Barr virus, cytomegalovirus, and human papilloma virus, there are also no reports on higher infection rates in patients with OAL [54,59].

\subsubsection{Autoimmune Diseases}

The detailed mechanisms of lymphomagenesis in the context of autoimmunity remain unclear. The occurrence of lymphomas in association with rheumatoid arthritis, Sjögren's syndrome, Hashimoto thyroiditis, and other autoimmune diseases is well described [60,61]. A meta-analysis of 20 studies including patients with the abovementioned autoimmune diseases revealed that lymphomas are more common in these patients than in healthy subjects [62]. The most common lymphoma subtype occurring in patients with autoimmune diseases is marginal-zone lymphoma [63]. Disease activity, the presence of rheumatoid factor, and/or cryoglobulinemia in patients with autoimmune diseases are prognostic factors for lymphoma development, reflecting a continuing immune stimulation [64]. Apoptotic resistance-mediated by high BCL2 expression, activation of NF- $\mathrm{KB}$, and overexpression of B-cell activating factor (BAFF)—is increased in autoimmune diseases [65]. Figure 2 provides a proposed scenario of OAMZL pathogenesis.

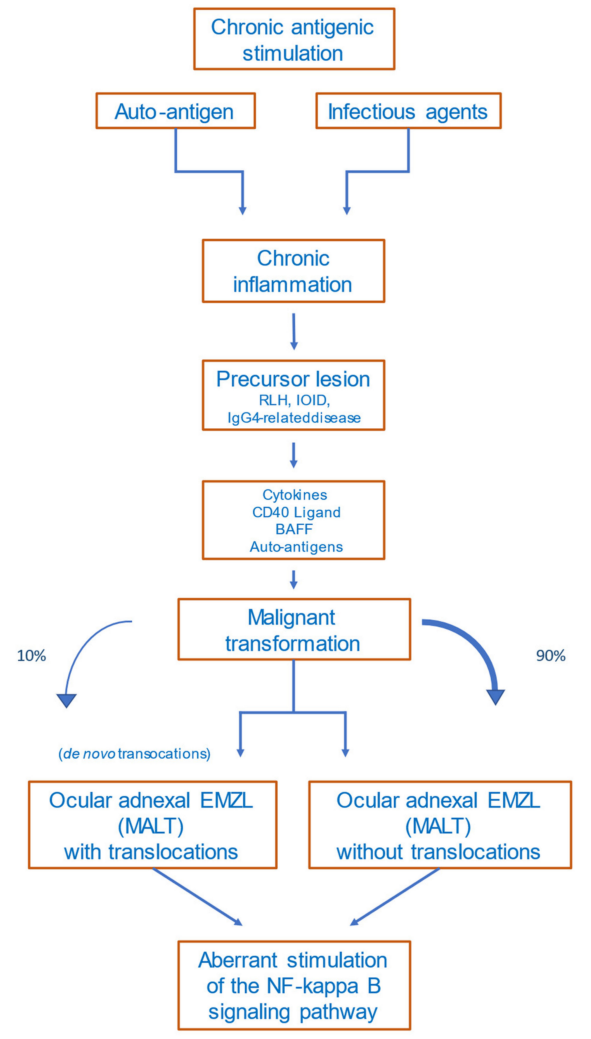

Figure 2. Proposed scheme of OAMZL pathogenesis. RLH: reactive lymphoid hyperplasia; IOID: idiopathic orbital inflammatory disease; BAFF: B-cell activating factor; EMZL: extranodal marginalzone lymphoma; MALT: mucosa-associated lymphatic tissue. 


\subsection{Chromosomal Aberrations}

\subsubsection{Translocations}

In OAMZL, chromosomal translocations leading to constitutive activation of the NF- $\mathrm{BB}$ signaling pathway have been described [22]; these include $t(11 ; 18)(\mathrm{q} 21 ; \mathrm{q} 21)$ / BIRC3-MALT1, often accompanied by a trisomy 3 [66], and $\mathrm{t}(14 ; 18)(\mathrm{q} 32 ; \mathrm{q} 21) / I G H-M A L T 1$ (Table 1). The $\mathrm{t}(11 ; 18)(\mathrm{q} 21 ; \mathrm{q} 21)$ juxtaposes BIRC3 (previously also known as API2) to MALT1, resulting in a fusion gene; this translocation has been detected in 10-15\% of OAL cases [67,68]. The $\mathrm{t}(14 ; 18)$ (q32; $\mathrm{q} 21)$ translocation brings the MALT1 gene under control of the IGH locus enhancers, causing constitutive expression of MALT1, and is present in around $5-10 \%$ of OAMZLs. MALT1 is a protease and an important mediator of canonical NF- $k B$ signaling [69].

Table 1. Genetic alterations of OAMZL.

\begin{tabular}{|c|c|c|c|c|}
\hline $\begin{array}{l}\text { Chromosomes or } \\
\text { Genes Affected }\end{array}$ & Type of Genetic Alteration & Pathway or Main Function & $\begin{array}{l}\text { Approximate } \\
\text { Frequency (\%) }\end{array}$ & References \\
\hline \multicolumn{5}{|c|}{ Chromosomal alterations } \\
\hline Trisomy 3 & Chromosomal gain & $\begin{array}{l}\text { unclear } \\
\text { (FOXP1?) }\end{array}$ & $30-60$ & [70-72] \\
\hline Trisomy 18 & Chromosomal gain & unclear & $20-55$ & {$[70-72]$} \\
\hline $\mathrm{t}(11 ; 18)(\mathrm{q} 21 ; \mathrm{q} 21)$ & BIRC3-MALT1 translocation & NF-kB pathway & $10-15$ & {$[68,73]$} \\
\hline $\mathrm{t}(14 ; 18)(\mathrm{q} 32 ; \mathrm{q} 21)$ & IGH-MALT1 translocation & NF-кB pathway & $5-10$ & {$[67,70,74]$} \\
\hline $\mathrm{t}(3 ; 14)(\mathrm{p} 14.1 ; \mathrm{q} 32)$ & FOXP1-IGH translocation & $\begin{array}{l}\text { B-cell development and } \\
\text { survival (NF-kB pathway) }\end{array}$ & $5-15$ & {$[75,76]$} \\
\hline \multicolumn{5}{|c|}{ Gene mutations } \\
\hline TNFAIP3 & $\begin{array}{c}\text { Deletions, non-synonymous } \\
\text { mutations }\end{array}$ & NF- $\kappa B$ pathway & $30-50$ & [77-81] \\
\hline MYD88 & $\begin{array}{l}\text { Non-synonymous mutations } \\
\text { (mostly p.L265P) }\end{array}$ & NF- $k B$ pathway & $5-35$ & {$[78,81-84]$} \\
\hline NOTCH1 & $\begin{array}{l}\text { Non-synonymous mutations } \\
\text { (mostly HD and PEST domains) }\end{array}$ & NOTCH pathway & $2-10$ & {$[78,80,85]$} \\
\hline $\mathrm{NOTCH} 2$ & $\begin{array}{l}\text { Non-synonymous mutations } \\
\text { (mostly TAD and PEST domains) }\end{array}$ & $\mathrm{NOTCH}$ pathway & $5-10$ & {$[78,86]$} \\
\hline KMT2D & Non-synonymous mutations & Epigenetic regulation & $5-20$ & {$[78,80,81,86]$} \\
\hline CREBBP & Non-synonymous mutations & Epigenetic regulation & 15 & {$[51,80]$} \\
\hline TBL1XR1 & $\begin{array}{l}\text { Non-synonymous mutations } \\
\text { (mostly WD40 domain) }\end{array}$ & $\begin{array}{l}\text { Regulation of nuclear } \\
\text { receptor activity (NF-kB and } \\
\text { AP1 pathway) }\end{array}$ & $10-20$ & {$[51,80,81,85]$} \\
\hline$J A K 3$ & \multirow{2}{*}{$\begin{array}{c}\text { Non-synonymous mutations } \\
\text { deletions, Non-synonymous } \\
\text { mutations }\end{array}$} & JAK/STAT signaling & $5-10$ & {$[51,81]$} \\
\hline CABIN1 & & NFAT signaling & $30 \%$ & [87] \\
\hline RHOA & $\begin{array}{c}\text { deletions, Non-synonymous } \\
\text { mutations }\end{array}$ & Rho signaling & $26 \%$ & [87] \\
\hline
\end{tabular}

Non-synonymous mutations: includes damaging point mutations, small insertions/deletions.

The $\mathrm{t}(3 ; 14)$ (p14.1;q32)/FOXP1-IGH was observed in around 5-15\% of OALs, and leads to constitutive expression of FOXP1 $[75,76,88]$. FOXP1 is a transcription factor that supports B-cell survival, and can cooperate with $\mathrm{NF}-\mathrm{kB}$, so that for this translocation event there is also a link to the NF-kB pathway [89].

Further translocations occur in OAMZL with lower prevalence. These include $t(1 ; 14)(p 22 ; q 34)$ juxtaposing BCL10 to the IGH locus, or $\mathrm{t}(5 ; 11)$ with unknown translocation partners [90]. Notably, translocations are observed in OAMZL at lower frequencies than in MALT lymphomas occurring in other regions, and the various EMZLs show distinct patterns of recurrent chromosomal translocations [88]. 


\subsubsection{Copy Number Variations}

The most frequent copy number variations in OAMZL are trisomy 3 and trisomy 18, in approximately $30-60 \%$ and $20-55 \%$ of patients, respectively (Table 1) [70,71]. Trisomy 3 is more common in persons above 50 years of age, whereas trisomy 18 is observed mostly in younger, female patients. The cases with trisomy 18 have more lymphoproliferative lesions, less nodularity, and are associated with recurrent disease [91]. The pathogenetic effect of these trisomies in OAMZL is unknown.

\subsection{Genetic Alterations in Particular Signaling Pathways}

\subsubsection{Nuclear Factor Kappa B (NF-kB) Pathway}

NF- $\mathrm{KB}$ is a transcription factor family that plays a critical role in B-cells' activation, development, and survival [92]. The NF-kB pathway is normally only transiently activated in $B$ cells by binding of various ligands to receptors, including Toll-like receptors, the TNF- $\alpha$ receptor, the BCR, CD40, and others. The intracellular signaling transduction is mediated via a canonical and a non-canonical pathway [88]. A major role of deregulated activation of this pathway in OAMZL is already indicated by the fact that the three most frequent chromosomal translocations of OAMZL cause, or at least contribute to, NF- $\mathrm{kB}$ activation, as discussed above. A further major driver for constitutive NF- $k B$ activation in OAMZL is genetic alterations leading to functional changes of TNF- $\alpha$-inducible protein 3 (TNFAIP3), previously also called A20. Somatic deletions and/or point mutations lead to inactivation of this negative regulator of the classical NF- $\mathrm{kB}$ pathway [79]. In OAMZL, destructive TNFAIP3 mutations and/or deletions were observed in $30-50 \%$ of cases $[77,80]$ (Table 1). TNFAIP3 is the most frequently mutated gene detected so far in OAMZL. It has been reported that IGH/MALT1 translocations are mutually exclusive with TNFAIP3 mutations/deletions in OAMZL [79], indicating that these are alternative mechanisms for deregulated NF-KB activation in OAMZL.

To identify potential mutations in further genes of the NF- $\mathrm{kB}$ signaling pathway, sequencing analyses were performed by several groups. In 24 OAMZL samples, sequencing of hotspots in the genes CARD11, MYD88, and CD79B, known to be frequently mutated in other B-cell lymphomas, revealed no mutations [93]. In a targeted sequencing approach of genes involved in the NF- $\mathrm{kB}$ signaling pathway performed by our team with 63 patients, mutations in TNFAIP3 (27\% of cases), MYD88 (19\%), and BCL10 (6\%) were observed [78]. Further genes, mutated to lower frequencies, were TNIP1, NFKBIA, BIRC3, CARD11, and $C D 79 B$. Only a few genes encoding components of the non-canonical NF- $\mathrm{KB}$ pathway were mutated (MAP3K14, BIRC3, and CYLD), whereas other mutated genes were involved in the canonical pathway [78]. A further study analyzing the frequency of MYD88 L265P mutations in primary OAL found the gene to be mutated in $36 \%$ of patients [82]. In a targeted next-generation sequencing (NGS) approach to OAL including 20 samples, with 17 of them being primary OAL, $25 \%$ of cases exhibited mutations in the TIR domain of MYD88 [83]. Two of the three studies mentioned carefully excluded lymphoplasmacytic lymphoma/Waldenström macroglobulinemia by analyzing paraproteins and plasmacytic differentiation-especially with IgM [78,83], which is necessary when analyzing MYD88 mutations. Further NGS-based approaches using whole genomes, whole exomes, and targeted sequencing confirmed and extended these findings $[51,80,86]$.

\subsubsection{NOTCH Pathway}

The NOTCH signaling pathway is important in cell differentiation; it is active in many cell types regulating cell development, differentiation, and homeostasis, and is involved in many malignant diseases, including lymphomas [94-96]. The NOTCH signaling pathway cross-interacts with the NF- $\mathrm{kB}$ signaling pathway as its upstream regulator [97-99]. Nonsynonymous NOTCH1 or NOTCH2 mutations were observed in up to $10 \%$ of OAMZLs, with a similar pattern as described for other B-cell lymphomas. There is a clustering of the mutations in the HD and PEST domains of NOTCH1, as well as downstream of the ankyrin repeats in the intracellular domain of NOTCH2 $[78,80]$. For both genes, these types of 
mutations cause a gain of function, as the inhibitory C-terminal PEST domains are removed or otherwise inactivated. Copy number gains in the NOTCH target HES4 may be a further mechanism of enforced NOTCH pathway activity in OAMZL [51,100].

\subsubsection{NFAT Signaling}

A recent exome sequencing study provided the first evidence for recurrent alterations in the NFAT signaling pathway in OAMZL. Frequent deletions and destructive mutations were detected in the gene encoding the negative NFAT signaling regulator CABIN1 (30\% of cases with mutations), as well as rarer mutations in NFAT members themselves and other NFAT signaling pathway components.

\subsection{Epigenetic Regulators}

Alterations in epigenetic modifiers occur in several types of lymphoma [101]; additionally, in OAMZL, genes encoding epigenetic regulators are mutated. Among these genes are KMT2D (approximately 5-20\% of cases) and CREBBP (ca. 15\%). In individual studies, mutations in the epigenetic regulators KMT2C and EP300 have been detected, such that a clear determination of the overall frequency of such alterations needs further investigation $[78,80,86]$. KMT2C and KMT2D, belonging to the mixed-lineage leukemia (MLL) family of histone methyltransferases, methylate Lys-4 of histone H3. Mutations leading to inactivation of these genes lead to diminished global H3K4 methylation in follicular and diffuse large B-cell lymphoma [102]. Conditional deletion of Kmt2d in different developmental stages of B cells in mice resulted in an increased number of germinal-center $\mathrm{B}$ cells end enhanced proliferation. From these results, the authors suggested the KMT2D acts as tumor suppressor gene. KMT2C, which functions very similarly to KMT2D, and can partially replace a loss of KMT2D, is therefore also supposed to be tumorigenic in case of a loss [103]. CREBBP and EP300 are related histone and non-histone acetyltransferases, which regulate transcriptional activity in several signaling pathways via chromatin remodeling. In follicular and diffuse large B-cell lymphoma, monoallelic deletions/mutations result in defects of acetylation of the oncoprotein BCL6 and the tumor suppressor p53.

\subsection{Additional Mutated Genes}

In addition to the genes in major signaling pathways or involving epigenetic regulators already mentioned, further genes recurrently mutated in OAMZL include TBL1XR1 [81]. TBL1XR1 is an essential regulator of transcriptional repression, and contributes to canonical NF- $\kappa B$ activation [104]. This gene can activate the transcription of transcription factors such as NF- $\kappa B$ and JUN [105], and may therefore contribute to the strong NF- $\kappa B$ activity in OAML. TBL1XR1 is mutated in various tumors and lymphomas, promoting tumor cell survival. In OAMZL, mutations were consistently detected in 10-20\% of cases, so TBL1XR1 is one of the most frequently mutated genes in this type of lymphoma (Table 1). TBL1XR1 mutations have been linked to a poor prognosis in aggressive lymphomas [106,107]. In a small cohort of patients with OAL of the MALT subtype, TBL1XR1 mutations were associated with unique morphometric phenotypes [108]; the cells exhibited significantly lower circularity and solidity as analyzed via computational digital image analysis.

The JAK/STAT signaling pathway is necessary for cytokine signaling and immune regulation, and plays an important role in various types of lymphoma [109]. Activating mutations in $J A K 3$, known to cause constitutive activation of the JAK/STAT signaling pathway, were observed in up to $10 \%$ of patients with OAMZL [51]. Interestingly, patients with mutant $J A K 3$ exhibited a shorter progression-free survival [51].

In a recent study, deletions and non-synonymous mutations in the RHOA gene were detected in $26 \%$ of OAMZL studies [87]; this points to a potential role of altered Rho signaling in OAMZL, but further studies are needed in order to clarify the consequences of the mutations detected in $R H O A$. 


\section{B-Cell Receptors of OAL}

Analysis of the rearranged immunoglobulin genes of B-cell lymphomas can reveal valuable insights into the specific B-cell subset from which a lymphoma derives. Moreover, in various types of B-cell lymphoma, the BCRs of the lymphoma cells recognize foreign or autoantigens, which may represent a major factor in lymphoma's pathogenesis [110]. Numerous studies of the IGHV genes of OAL—mostly those of the MALT typeshowed that in nearly all cases the lymphoma cells carried somatically mutated IGHV genes [76,111-116]; this revealed the origin of OAL from germinal-center-experienced $B$ cells, as the process of somatic hypermutation, which produces such mutations, takes place specifically in germinal-center B cells [117]. In a substantial fraction of cases, there were signs of low-level ongoing hypermutation, indicating that the lymphoma cells had retained some features of germinal-center B cells, and may still be antigen-driven $[76,112,113,116]$. A biased IGHV gene usage can be a further indication that the BCRs of a particular type of lymphoma are specific to a limited set of antigens. Numerous studies of OAMZL have addressed this issue and, indeed, revealed that some IGHV genes were more frequently used than expected based on their usage in the normal B-cell population. The fact that not all studies found the same biased IGHV gene usage may be due to the often rather small number of cases studied, and the fact that most studies involved cases from distinct continents, suggesting that geographic conditions may influence IGHV gene usage. The IGHV genes repeatedly reported to be frequently rearranged by OAL clones include IGHV4-34, IGHV3-7, IGHV3-23, and IGHV3-30 [76,112,113,115,116,118]. Several of these genes are known to be frequently used by autoantibodies, raising the suspicion that the BCRs of OAL may often be autoreactive; this is also implied by the observed link between these lymphomas and autoimmune diseases, as discussed above. This hypothesis was experimentally validated by showing autoreactivity of five out of five antibodies tested [119].

Taken together, the numerous studies on the BCR sequence features have provided strong indication that OAL is derived from antigen-experienced (post) germinal-center $B$ cells that have a biased IGHV usage and are often autoreactive. The chronic stimulation of such autoreactive B cells may be an important factor in the transformation of these cells into malignant OAL clones.

The mechanisms and pathways involved in the pathogenesis of OAMZL are depicted in Figure 3.

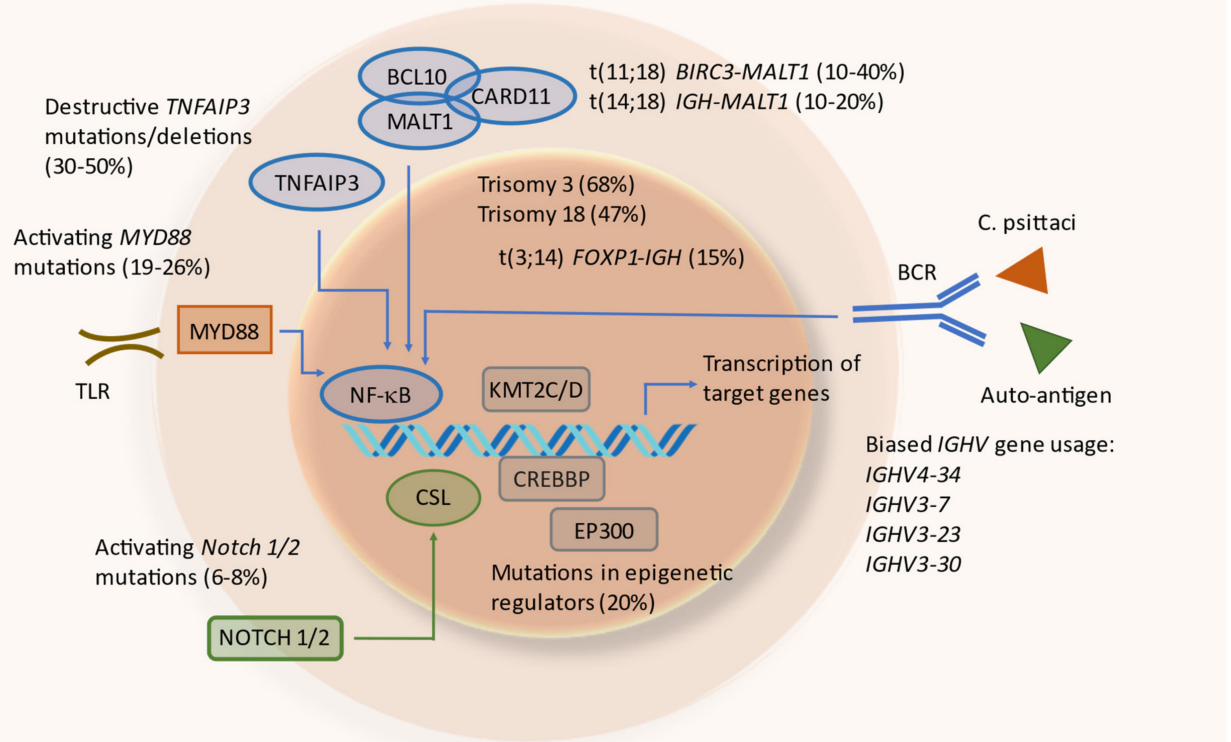

Figure 3. Mechanisms and pathways involved in the pathogenesis of OAMZL. TLR: toll-like receptor; C. psittaci: Chlamydophila psittaci. 


\section{Altered DNA Methylation}

Altered DNA methylation plays a significant role in the pathogenesis of marginal-zone lymphomas [120]. Promoter methylation in TNFAIP3 - which is also frequently mutated in OAMZL, as discussed above-was observed in 19\% of OAMZLs, and was associated with hemizygous deletion of TNFAIP3, but mutually exclusive with mutations in the gene. Promoter methylation seems to have an additive effect in the regulation of A20 expression, since promoter methylation in addition to hemizygous deletion resulted in lower transcript expression [79].

Choung et al. investigated aberrant promotor methylation of known or suspected tumor-suppressor genes in OAMZL, as well as the potential association with C. psittaci infections in 35 cases [121]; they observed CpG island methylation in nine genes, which was not the case in any of the 13 control cases. C. psittaci was detected in $75 \%$ of cases available for analysis. ECAD hypermethylation was significantly higher in C. psittaci-positive cases, but was not correlated with clinical characteristics. A comparison of genome-wide DNA methylation profiles in relation to C. psittaci infection status and response to doxycycline treatment in OAMZL revealed distinct methylation patterns. The methylation status of DUSP22 was likely attributable to infection, whereas methylation of the genes IRAK1 and CXCL6 may reflect treatment response [122].

\section{Altered microRNA Expression}

The role of microRNAs (miRNAs) in OAMZL is not well understood. Hother et al. studied miRNA expression via microarray analysis in a cohort of 18 OAMZLs, 15 of them being primary lymphomas. Comparing the results to aggressive lymphomas, the authors observed MYC- and NFKB1-mediated dysregulation of miRNA expression in the samples with aggressive lymphomas; they concluded the existence of fundamental differences in miRNA expression between OAMZLs and diffuse large B-cell lymphomas, mainly due to differences in the MYC and NF- $\mathrm{KB}$ regulatory pathways [123].

\section{Microenvironment}

In the absence of a local trigger such as C. psittaci, it is unclear why EMZLs arise in the specific location of the ocular adnexa. The ocular adnexa lack lymphatic tissue, which contains germinal centers. Lymphocytes therefore have to migrate and home to the ocular adnexa. In an immunohistochemical analysis of 91 lymphoma cases, including 28 OAMZLs, homing and trafficking of lymphocytes by chemokines, sphingosine-1-phosphate, chemokine receptors, and integrins was analyzed [124]. Comparing lymphomas arising in secondary lymphatic organs with OALs, distinct patterns of lymphocyte homing molecules were observed. Analysis of molecules responsible for entry in extranodal sites-such as CXCR4, CXCL12, and $\alpha 4 \beta 1$ integrin-revealed a high CXCR4 expression for EMZL. CXCL12 expression was higher for extranodal lymphomas than for nodal lymphomas, providing a strong homing signal. Retention in the tissue was mediated by CXCR5 and CXCL13 expression [124].

The role of a specific microenvironment in OAMZL needs to be further analyzed. Kim et al. analyzed tumor-infiltrating T cells [125]; their group was particularly interested in the clinical significance of tumor-infiltrating $\mathrm{FOXP3}^{+} \mathrm{T}$ cells in patients with OAMZL. Biopsy specimens of 42 patients with and without treatment were stained for FOXP3 expression. Treatment was chemotherapy, radiotherapy, doxycycline, or a watch and wait concept. A complete response was observed in $50 \%$ of patients. A high number of $\mathrm{FOXP}^{+} \mathrm{T}$ cells was associated with a higher rate of complete response and a tendency towards a prolonged progression-free survival [125].

In 2013, Kinoshita et al. investigated the role of the vascular endothelial growth factor (VEGF) in OAMZL and RLH. In 22 OAMZLs and 16 reactive samples the VEGF and CD20 positivity were higher in the lymphomas than in the RLH samples. Microvessel density as determined by anti-CD34 staining showed a significant positive correlation 
with VEGF/CD20 expression. The authors suggested a significant role for VEGF in the pathogenesis and tumor angiogenesis of OAMZL [126].

\section{Conclusions}

There is now compelling indication that continuous antigenic stimulation of B cells by particular bacterial infections or autoantigens is the basis for the development of OAMZL. Such an initial and prolonged antigenic triggering of $B$ cells is a general feature of marginalzone B-cell lymphomas, as well as several other types of B-cell lymphoma [110]. Although the lymphoma is located outside the secondary lymphoid organs, it is obvious that a Tcell-dependent germinal-center reaction plays an essential role in the pathogenesis of lymphoma, as nearly all cases carry somatically mutated IGV genes, representing a genetic trait of a germinal-center reaction. This reaction likely plays a role in the pathogenesis of OAMZL not only by generating long-lived and presumably high-affinity B cells, but also by promoting chromosomal translocations and mutations in non-IG genes [127]. OAMZL therefore belongs to the large group of germinal-center-derived B-cell lymphomas $[127,128]$. A further similarity not only to other marginal-zone B-cell lymphomas, but also to various other lymphoma types (e.g., many diffuse large B-cell lymphomas and Hodgkin lymphoma), is the major role of constitutive NF- $\mathrm{KB}$ activity, mediated by various types of chromosomal translocations and mutations in proto-oncogenes and tumor-suppressor genes [129]. As other genetic alterations detected in OAMZL have also been found in other types of lymphomas, there is (so far) no distinct genetic or epigenetic event known that is specific to only this lymphoma. It is likely that it is the particular combination of antigenic specificities of the lymphoma cells, microenvironmental interactions, and genetic and epigenetic alterations that specifies OAMZL as a distinct type of human B-cell lymphoma.

Author Contributions: Conceptualization and writing-original draft preparation, P.J. and R.K.; writing - review and editing, A.E. All authors have read and agreed to the published version of the manuscript.

Funding: Our own work on OAL was funded by the Werner Jackstädt-Stiftung. P.J. was supported by the IFORES program of the Medical Faculty of the University Duisburg-Essen.

Acknowledgments: We thank the collaborators and technical assistants who contributed to our own studies on the pathogenesis of OAMZL. We also thank Ulrich Dührsen for his generous support of our work.

Conflicts of Interest: The authors declare no conflict of interest.

\section{References}

1. Dutton, J. Atlas of Clinical and Surgical Orbital Anatomy, 2nd ed.; W.B. Saunders Co. Ltd.: Philadelphia, PA, USA; Elsevier: London, UK, 2018.

2. $\quad$ Freddo, T.C.E. Anatomy of the Eye and Orbit, 1st ed.; Wolters Kluwer Health: Philadelphia, PA, USA, 2018.

3. Swerdlow, S.H.; Campo, E.; Pileri, S.A.; Harris, N.L.; Stein, H.; Siebert, R.; Advani, R.; Ghielmini, M.; Salles, G.A.; Zelenetz, A.D.; et al. The 2016 revision of the World Health Organization classification of lymphoid neoplasms. Blood 2016, 127, 2375-2390. [CrossRef] [PubMed]

4. Chung, H.U.; Son, J.H. Ocular adnexal mucosa-associated lymphoid tissue lymphoma: A narrative review. J. Yeungnam Med. Sci. 2022, 39, 3-11. [CrossRef]

5. Kalogeropoulos, D.; Papoudou-Bai, A.; Kanavaros, P.; Kalogeropoulos, C. Ocular adnexal marginal zone lymphoma of mucosaassociated lymphoid tissue. Clin. Exp. Med. 2018, 18, 151-163. [CrossRef] [PubMed]

6. Olsen, T.G.; Holm, F.; Mikkelsen, L.H.; Rasmussen, P.K.; Coupland, S.E.; Esmaeli, B.; Finger, P.T.; Graue, G.F.; Grossniklaus, H.E.; Honavar, S.G.; et al. Orbital Lymphoma-An International Multicenter Retrospective Study. Am. J. Ophthalmol. $2019,199,44-57$. [CrossRef] [PubMed]

7. Sassone, M.; Ponzoni, M.; Ferreri, A.J. Ocular adnexal marginal zone lymphoma: Clinical presentation, pathogenesis, diagnosis, prognosis, and treatment. Best Pract. Res. Clin. Haematol. 2017, 30, 118-130. [CrossRef]

8. Coupland, S.E.; Krause, L.; Delecluse, H.J.; Anagnostopoulos, I.; Foss, H.D.; Hummel, M.; Bornfeld, N.; Lee, W.R.; Stein, H. Lymphoproliferative lesions of the ocular adnexa. Analysis of 112 cases. Ophthalmology 1998, 105, 1430-1441. [CrossRef]

9. Ferry, J.A.; Fung, C.Y.; Zukerberg, L.; Lucarelli, M.J.; Hasserjian, R.P.; Preffer, F.I.; Harris, N.L. Lymphoma of the ocular adnexa: A study of 353 cases. Am. J. Surg. Pathol. 2007, 31, 170-184. [CrossRef] 
10. Olszewski, A.J.; Castillo, J.J. Survival of patients with marginal zone lymphoma: Analysis of the Surveillance, Epidemiology, and End Results database. Cancer 2013, 119, 629-638. [CrossRef]

11. Holm, F.; Mikkelsen, L.H.; Kamper, P.; Rasmussen, P.K.; Larsen, T.S.; Sjo, L.D.; Heegaard, S. Ocular adnexal lymphoma in Denmark: A nationwide study of 387 cases from 1980 to 2017. Br. J. Ophthalmol. 2021, 105, 914-920. [CrossRef]

12. Rootman, D.B.; Mavrikakis, I.; Connors, J.M.; Rootman, J. Primary, unilateral ocular adnexal lymphoma: Disease progression and long-term survival. Ophthalmic Plast. Reconstr. Surg. 2011, 27, 405-409. [CrossRef]

13. Sjo, L.D. Ophthalmic lymphoma: Epidemiology and pathogenesis. Acta Ophthalmol. 2009, 87, 1-20. [CrossRef] [PubMed]

14. Svendsen, F.H.; Rasmussen, P.K.; Coupland, S.E.; Esmaeli, B.; Finger, P.T.; Graue, G.F.; Grossniklaus, H.E.; Honavar, S.G.; Khong, J.J.; McKelvie, P.A.; et al. Lymphoma of the Eyelid-An International Multicenter Retrospective Study. Am. J. Ophthalmol. 2017, 177, 58-68. [CrossRef] [PubMed]

15. Tanenbaum, R.E.; Galor, A.; Dubovy, S.R.; Karp, C.L. Classification, diagnosis, and management of conjunctival lymphoma. Eye Vis. 2019, 6, 22. [CrossRef] [PubMed]

16. Anderson, N.G.; Wojno, T.H.; Grossniklaus, H.E. Clinicopathologic findings from lacrimal sac biopsy specimens obtained during dacryocystorhinostomy. Ophthalmic Plast. Reconstr. Surg. 2003, 19, 173-176. [CrossRef]

17. Vest, S.D.; Mikkelsen, L.H.; Holm, F.; Rasmussen, P.K.; Hindso, T.G.; Knudsen, M.K.H.; Coupland, S.E.; Esmaeli, B.; Finger, P.T.; Graue, G.F.; et al. Lymphoma of the Lacrimal Gland-An International Multicenter Retrospective Study. Am. J. Ophthalmol. 2020, 219, 107-120. [CrossRef]

18. Stefanovic, A.; Lossos, I.S. Extranodal marginal zone lymphoma of the ocular adnexa. Blood 2009, 114, 501-510. [CrossRef]

19. Freeman, C.; Berg, J.W.; Cutler, S.J. Occurrence and prognosis of extranodal lymphomas. Cancer 1972, 29, 252-260. [CrossRef]

20. Moslehi, R.; Devesa, S.S.; Schairer, C.; Fraumeni, J.F., Jr. Rapidly increasing incidence of ocular non-hodgkin lymphoma. J. Natl. Cancer Inst. 2006, 98, 936-939. [CrossRef]

21. Cerhan, J.R.; Habermann, T.M. Epidemiology of Marginal Zone Lymphoma. Ann. Lymphoma 2021, 5. [CrossRef]

22. Isaacson, P.G.; Du, M.Q. MALT lymphoma: From morphology to molecules. Nat. Rev. Cancer 2004, 4, 644-653. [CrossRef]

23. Coupland, S.E.; Hellmich, M.; Auw-Haedrich, C.; Lee, W.R.; Anagnostopoulos, I.; Stein, H. Plasmacellular differentiation in extranodal marginal zone B cell lymphomas of the ocular adnexa: An analysis of the neoplastic plasma cell phenotype and its prognostic significance in 136 cases. Br. J. Ophthalmol. 2005, 89, 352-359. [CrossRef]

24. Coupland, S.E.; Damato, B. Lymphomas involving the eye and the ocular adnexa. Curr. Opin. Ophthalmol. 2006, 17, 523-531. [CrossRef]

25. Matsuo, T.; Ichimura, K.; Okada, H.; Shinagawa, K.; Fukushima, K.; Okano, M.; Otsuka, M.; Yoshino, T. Clonal analysis of bilateral, recurrent, or systemically multifocal ocular adnexal lymphoma. J. Clin. Exp. Hematop. 2010, 50, 27-38. [CrossRef] [PubMed]

26. Sagiv, O.; Thakar, S.D.; Manning, J.T.; Kandl, T.J.; Fayad, L.E.; Fowler, N.; Hagemeister, F.B.; Fanale, M.A.; Pinnix, C.C.; Samaniego, F.; et al. Prevalence of a Histologic Change of Ocular Adnexal Lymphoma in Patients With a History of Lymphoma. Ophthalmic Plast. Reconstr. Surg. 2019, 35, 243-246. [CrossRef]

27. Das, D.; Deka, P.; Bhattacharjee, K.; Das, J.K.; Kuri, G.C.; Bhattaacharjee, H.; Deori, N.; Deshmukh, S.; Paidi, R.; Deka, A. Idiopathic inflammatory diseases of orbit and ocular adnexa: Histopathological and immunochemical analysis. Indian J. Ophthalmol. 2019, 67, 1993-1995. [CrossRef] [PubMed]

28. Ferreri, A.J.; Dolcetti, R.; Du, M.Q.; Doglioni, C.; Resti, A.G.; Politi, L.S.; De Conciliis, C.; Radford, J.; Bertoni, F.; Zucca, E.; et al. Ocular adnexal MALT lymphoma: An intriguing model for antigen-driven lymphomagenesis and microbial-targeted therapy. Ann. Oncol. 2008, 19, 835-846. [CrossRef] [PubMed]

29. Go, H.; Kim, J.E.; Kim, Y.A.; Chung, H.K.; Khwarg, S.I.; Kim, C.W.; Jeon, Y.K. Ocular adnexal IgG4-related disease: Comparative analysis with mucosa-associated lymphoid tissue lymphoma and other chronic inflammatory conditions. Histopathology 2012 60, 296-312. [CrossRef]

30. Kubota, T.; Moritani, S.; Yoshino, T.; Nagai, H.; Terasaki, H. Ocular adnexal marginal zone B cell lymphoma infiltrated by IgG4-positive plasma cells. J. Clin. Pathol. 2010, 63, 1059-1065. [CrossRef]

31. Nishida, K.; Sogabe, Y.; Makihara, A.; Senoo, A.; Morimoto, H.; Takeuchi, M.; Gion, Y.; Yoshino, T.; Sato, Y. Ocular adnexal marginal zone lymphoma arising in a patient with IgG4-related ophthalmic disease. Mod. Rheumatol. 2019, 29, 383-387. [CrossRef]

32. Ohno, K.; Sato, Y.; Ohshima, K.; Takata, K.; Miyata-Takata, T.; Takeuchi, M.; Gion, Y.; Tachibana, T.; Orita, Y.; Ito, T.; et al. A subset of ocular adnexal marginal zone lymphomas may arise in association with IgG4-related disease. Sci. Rep. 2015, 5, 13539. [CrossRef] [PubMed]

33. Sohn, E.J.; Ahn, H.B.; Roh, M.S.; Jung, W.J.; Ryu, W.Y.; Kwon, Y.H. Immunoglobulin G4 (IgG4)-Positive Ocular Adnexal MucosaAssociated Lymphoid Tissue Lymphoma and Idiopathic Orbital Inflammation. Ophthalmic Plast. Reconstr. Surg. 2018, 34, 313-319. [CrossRef]

34. Li, K.M.; Xu, M.H.; Wu, X.; He, W.M. The Expression of IgG and IgG4 in Orbital MALT Lymphoma: The Similarities and Differences of IgG4-Related Diseases. OncoTargets Ther. 2020, 13, 5755-5761. [CrossRef]

35. Karadeniz, H.; Vaglio, A. IgG4-related disease: A contemporary review. Turk. J. Med. Sci. 2020, 50, 1616-1631. [CrossRef]

36. Nishikori, A.; Nishimura, Y.; Shibata, R.; Ohshima, K.I.; Gion, Y.; Ikeda, T.; Nishimura, M.F.; Yoshino, T.; Sato, Y. Upregulated Expression of Activation-Induced Cytidine Deaminase in Ocular Adnexal Marginal Zone Lymphoma with IgG4-Positive Cells. Int. J. Mol. Sci. 2021, 22, 4083. [CrossRef] 
37. Du, M.Q. MALT lymphoma: A paradigm of NF-kappaB dysregulation. Semin. Cancer Biol. 2016, 39, 49-60. [CrossRef] [PubMed]

38. Melenotte, C.; Mezouar, S.; Mege, J.L.; Gorvel, J.P.; Kroemer, G.; Raoult, D. Bacterial infection and non-Hodgkin's lymphoma. Crit. Rev. Microbiol. 2020, 46, 270-287. [CrossRef] [PubMed]

39. Biernat, M.M.; Wrobel, T. Bacterial Infection and Non-Hodgkin B-Cell Lymphoma: Interactions between Pathogen, Host and the Tumor Environment. Int. J. Mol. Sci. 2021, 22, 7372. [CrossRef]

40. Collina, F.; De Chiara, A.; De Renzo, A.; De Rosa, G.; Botti, G.; Franco, R. Chlamydia psittaci in ocular adnexa MALT lymphoma: A possible role in lymphomagenesis and a different geographical distribution. Infect. Agents Cancer 2012, 7, 8. [CrossRef]

41. Ferreri, A.J.; Guidoboni, M.; Ponzoni, M.; De Conciliis, C.; Dell’Oro, S.; Fleischhauer, K.; Caggiari, L.; Lettini, A.A.; Dal Cin, E.; Ieri, R.; et al. Evidence for an association between Chlamydia psittaci and ocular adnexal lymphomas. J. Natl. Cancer Inst. 2004, 96, 586-594. [CrossRef] [PubMed]

42. Yoo, C.; Ryu, M.H.; Huh, J.; Park, J.H.; Kang, H.J.; Ahn, H.S.; Lee, Y.; Kim, M.J.; Lee, H.; Kim, T.W.; et al. Chlamydia psittaci infection and clinicopathologic analysis of ocular adnexal lymphomas in Korea. Am. J. Hematol. 2007, 82, 821-823. [CrossRef] [PubMed]

43. Daibata, M.; Nemoto, Y.; Togitani, K.; Fukushima, A.; Ueno, H.; Ouchi, K.; Fukushi, H.; Imai, S.; Taguchi, H. Absence of Chlamydia psittaci in ocular adnexal lymphoma from Japanese patients. Br. J. Haematol. 2006, 132, 651-652. [CrossRef]

44. De Cremoux, P.; Subtil, A.; Ferreri, A.J.; Vincent-Salomon, A.; Ponzoni, M.; Chaoui, D.; Arnaud, P.; Lumbroso-Le Rouic, L.; Sacchetti, F.; Dendale, R.; et al. Re: Evidence for an association between Chlamydia psittaci and ocular adnexal lymphomas. J. Natl. Cancer Inst. 2006, 98, 365-366. [CrossRef] [PubMed]

45. Mulder, M.M.; Heddema, E.R.; Pannekoek, Y.; Faridpooya, K.; Oud, M.E.; Schilder-Tol, E.; Saeed, P.; Pals, S.T. No evidence for an association of ocular adnexal lymphoma with Chlamydia psittaci in a cohort of patients from the Netherlands. Leuk. Res. 2006, 30, 1305-1307. [CrossRef]

46. Rosado, M.F.; Byrne, G.E., Jr.; Ding, F.; Fields, K.A.; Ruiz, P.; Dubovy, S.R.; Walker, G.R.; Markoe, A.; Lossos, I.S. Ocular adnexal lymphoma: A clinicopathologic study of a large cohort of patients with no evidence for an association with Chlamydia psittaci. Blood 2006, 107, 467-472. [CrossRef]

47. Vargas, R.L.; Fallone, E.; Felgar, R.E.; Friedberg, J.W.; Arbini, A.A.; Andersen, A.A.; Rothberg, P.G. Is there an association between ocular adnexal lymphoma and infection with Chlamydia psittaci? The University of Rochester experience. Leuk. Res. 2006 30, 547-551. [CrossRef]

48. Zhang, G.S.; Winter, J.N.; Variakojis, D.; Reich, S.; Lissner, G.S.; Bryar, P.; Regner, M.; Mangold, K.; Kaul, K. Lack of an association between Chlamydia psittaci and ocular adnexal lymphoma. Leuk. Lymphoma 2007, 48, 577-583. [CrossRef]

49. Gracia, E.; Froesch, P.; Mazzucchelli, L.; Martin, V.; Rodriguez-Abreu, D.; Jimenez, J.; Melgares, M.; Santos, D.; Capo, V.; Cavalli, F.; et al. Low prevalence of Chlamydia psittaci in ocular adnexal lymphomas from Cuban patients. Leuk. Lymphoma 2007, 48, 104-108. [CrossRef]

50. Matthews, J.M.; Moreno, L.I.; Dennis, J.; Byrne, G.E., Jr.; Ruiz, P.; Dubovy, S.R.; Lossos, I.S. Ocular Adnexal Lymphoma: No evidence for bacterial DNA associated with lymphoma pathogenesis. Br. J. Haematol. 2008, 142, 246-249. [CrossRef]

51. Johansson, P.; Klein-Hitpass, L.; Budeus, B.; Kuhn, M.; Lauber, C.; Seifert, M.; Roeder, I.; Pfortner, R.; Stuschke, M.; Dührsen, U.; et al. Identifying Genetic Lesions in Ocular Adnexal Extranodal Marginal Zone Lymphomas of the MALT Subtype by Whole Genome, Whole Exome and Targeted Sequencing. Cancers 2020, 12, 986. [CrossRef] [PubMed]

52. Travaglino, A.; Pace, M.; Varricchio, S.; Russo, D.; Pugliese, N.; Severino, A.; Picardi, M.; Pane, F.; Insabato, L.; Staibano, S.; et al Involvement of Helicobacter Pylori in Ocular Adnexa Lymphoma. Pathol. Oncol. Res. 2020, 26, 2075-2081. [CrossRef] [PubMed]

53. Kalin-Hajdu, E.; Bernier-Turmel, F.; Frost, E.; Labbe, A.C.; Couture, S.; Wong, J.; Boulos, P.R.; Codere, F.; Hardy, I. Helicobacter pylori Infection of the Gastric Mucosa and Ocular Adnexa-Lack of Association with Ocular Adnexal Lymphoma. Ophthalmic Plast. Reconstr. Surg. 2021, 37, S1-S5. [CrossRef]

54. Mollerup, S.; Mikkelsen, L.H.; Hansen, A.J.; Heegaard, S. High-throughput sequencing reveals no viral pathogens in eight cases of ocular adnexal extranodal marginal zone B-cell lymphoma. Exp. Eye Res. 2019, 185, 107677. [CrossRef]

55. De Sanjose, S.; Benavente, Y.; Vajdic, C.M.; Engels, E.A.; Morton, L.M.; Bracci, P.M.; Spinelli, J.J.; Zheng, T.; Zhang, Y.; Franceschi, S.; et al. Hepatitis C and non-Hodgkin lymphoma among 4784 cases and 6269 controls from the International Lymphoma Epidemiology Consortium. Clin. Gastroenterol. Hepatol. 2008, 6, 451-458. [CrossRef] [PubMed]

56. Tang, A.; Hallouch, O.; Chernyak, V.; Kamaya, A.; Sirlin, C.B. Epidemiology of hepatocellular carcinoma: Target population for surveillance and diagnosis. Abdom. Radiol. 2018, 43, 13-25. [CrossRef]

57. Couronne, L.; Bachy, E.; Roulland, S.; Nadel, B.; Davi, F.; Armand, M.; Canioni, D.; Michot, J.M.; Visco, C.; Arcaini, L.; et al. From hepatitis C virus infection to B-cell lymphoma. Ann. Oncol. 2018, 29, 92-100. [CrossRef]

58. Gibson, T.M.; Morton, L.M.; Shiels, M.S.; Clarke, C.A.; Engels, E.A. Risk of non-Hodgkin lymphoma subtypes in HIV-infected people during the HAART era: A population-based study. AIDS 2014, 28, 2313-2318. [CrossRef] [PubMed]

59. Verma, V.; Shen, D.; Sieving, P.C.; Chan, C.C. The role of infectious agents in the etiology of ocular adnexal neoplasia. Surv. Ophthalmol. 2008, 53, 312-331. [CrossRef] [PubMed]

60. Wohrer, S.; Troch, M.; Streubel, B.; Zwerina, J.; Skrabs, C.; Formanek, M.; Hauff, W.; Hoffmann, M.; Mullauer, L.; Chott, A.; et al. MALT lymphoma in patients with autoimmune diseases: A comparative analysis of characteristics and clinical course. Leukemia 2007, 21, 1812-1818. [CrossRef] 
61. Smedby, K.E.; Vajdic, C.M.; Falster, M.; Engels, E.A.; Martinez-Maza, O.; Turner, J.; Hjalgrim, H.; Vineis, P.; Costantini, A.S.; Bracci, P.M.; et al. Autoimmune disorders and risk of non-Hodgkin lymphoma subtypes: A pooled analysis within the InterLymph Consortium. Blood 2008, 111, 4029-4038. [CrossRef]

62. Zintzaras, E.; Voulgarelis, M.; Moutsopoulos, H.M. The risk of lymphoma development in autoimmune diseases: A meta-analysis. Arch. Intern. Med. 2005, 165, 2337-2344. [CrossRef]

63. Royer, B.; Cazals-Hatem, D.; Sibilia, J.; Agbalika, F.; Cayuela, J.M.; Soussi, T.; Maloisel, F.; Clauvel, J.P.; Brouet, J.C.; Mariette, X. Lymphomas in patients with Sjogren's syndrome are marginal zone B-cell neoplasms, arise in diverse extranodal and nodal sites, and are not associated with viruses. Blood 1997, 90, 766-775. [CrossRef] [PubMed]

64. Nocturne, G.; Virone, A.; Ng, W.F.; Le Guern, V.; Hachulla, E.; Cornec, D.; Daien, C.; Vittecoq, O.; Bienvenu, B.; Marcelli, C.; et al. Rheumatoid Factor and Disease Activity Are Independent Predictors of Lymphoma in Primary Sjogren's Syndrome. Arthritis Rheumatol. 2016, 68, 977-985. [CrossRef] [PubMed]

65. Mackay, F.; Woodcock, S.A.; Lawton, P.; Ambrose, C.; Baetscher, M.; Schneider, P.; Tschopp, J.; Browning, J.L. Mice transgenic for BAFF develop lymphocytic disorders along with autoimmune manifestations. J. Exp. Med. 1999, 190, 1697-1710. [CrossRef] [PubMed]

66. Wotherspoon, A.C.; Pan, L.X.; Diss, T.C.; Isaacson, P.G. Cytogenetic study of B-cell lymphoma of mucosa-associated lymphoid tissue. Cancer Genet. Cytogenet. 1992, 58, 35-38. [CrossRef]

67. Streubel, B.; Simonitsch-Klupp, I.; Mullauer, L.; Lamprecht, A.; Huber, D.; Siebert, R.; Stolte, M.; Trautinger, F.; Lukas, J.; Puspok, A.; et al. Variable frequencies of MALT lymphoma-associated genetic aberrations in MALT lymphomas of different sites. Leukemia 2004, 18, 1722-1726. [CrossRef]

68. Ye, H.; Liu, H.; Attygalle, A.; Wotherspoon, A.C.; Nicholson, A.G.; Charlotte, F.; Leblond, V.; Speight, P.; Goodlad, J.; Lavergne-Slove, A.; et al. Variable frequencies of $\mathrm{t}(11 ; 18)(\mathrm{q} 21 ; \mathrm{q} 21)$ in MALT lymphomas of different sites: Significant association with CagA strains of H pylori in gastric MALT lymphoma. Blood 2003, 102, 1012-1018. [CrossRef]

69. Hamoudi, R.A.; Appert, A.; Ye, H.; Ruskone-Fourmestraux, A.; Streubel, B.; Chott, A.; Raderer, M.; Gong, L.; Wlodarska, I.; De Wolf-Peeters, C.; et al. Differential expression of NF-kappaB target genes in MALT lymphoma with and without chromosome translocation: Insights into molecular mechanism. Leukemia 2010, 24, 1487-1497. [CrossRef]

70. Tanimoto, K.; Sekiguchi, N.; Yokota, Y.; Kaneko, A.; Watanabe, T.; Maeshima, A.M.; Matsuno, Y.; Harada, M.; Tobinai, K.; Kobayashi, Y. Fluorescence in situ hybridization (FISH) analysis of primary ocular adnexal MALT lymphoma. BMC Cancer 2006, 6, 249. [CrossRef]

71. Takahashi, H.; Usui, Y.; Ueda, S.; Yamakawa, N.; Sato-Otsubo, A.; Sato, Y.; Ogawa, S.; Goto, H. Genome-Wide Analysis of Ocular Adnexal Lymphoproliferative Disorders Using High-Resolution Single Nucleotide Polymorphism Array. Investig. Ophthalmol. Vis. Sci. 2015, 56, 4156-4165. [CrossRef]

72. Schiby, G.; Polak-Charcon, S.; Mardoukh, C.; Rosenblatt, K.; Goldberg, I.; Kneller, A.; Rosner, M.; Kopolovic, J. Orbital marginal zone lymphomas: An immunohistochemical, polymerase chain reaction, and fluorescence in situ hybridization study. Hum. Pathol. 2007, 38, 435-442. [CrossRef]

73. Takada, S.; Yoshino, T.; Taniwaki, M.; Nakamura, N.; Nakamine, H.; Oshima, K.; Sadahira, Y.; Inagaki, H.; Oshima, K.; Tadaatsu, A. Involvement of the chromosomal translocation $\mathrm{t}(11 ; 18)$ in some mucosa-associated lymphoid tissue lymphomas and diffuse large B-cell lymphomas of the ocular adnexa: Evidence from multiplex reverse transcriptase-polymerase chain reaction and fluorescence in situ hybridization on using formalin-fixed, paraffin-embedded specimens. Mod. Pathol. 2003, 16, 445-452. [CrossRef] [PubMed]

74. Zhu, D.; Ikpatt, O.F.; Dubovy, S.R.; Lossos, C.; Natkunam, Y.; Chapman-Fredricks, J.R.; Fan, Y.S.; Lossos, I.S. Molecular and genomic aberrations in Chlamydophila psittaci negative ocular adnexal marginal zone lymphomas. Am. J. Hematol. 2013, 88, 730-735. [CrossRef] [PubMed]

75. Streubel, B.; Vinatzer, U.; Lamprecht, A.; Raderer, M.; Chott, A. T(3;14)(p14.1;q32) involving IGH and FOXP1 is a novel recurrent chromosomal aberration in MALT lymphoma. Leukemia 2005, 19, 652-658. [CrossRef] [PubMed]

76. Adam, P.; Haralambieva, E.; Hartmann, M.; Mao, Z.; Ott, G.; Rosenwald, A. Rare occurrence of IgVH gene translocations and restricted IgVH gene repertoire in ocular MALT-type lymphoma. Haematologica 2008, 93, 319-320. [CrossRef]

77. Bi, Y.; Zeng, N.; Chanudet, E.; Huang, Y.; Hamoudi, R.A.; Liu, H.; Dong, G.; Watkins, A.J.; Ley, S.C.; Zou, L.; et al. A20 inactivation in ocular adnexal MALT lymphoma. Haematologica 2012, 97, 926-930. [CrossRef]

78. Johansson, P.; Klein-Hitpass, L.; Grabellus, F.; Arnold, G.; Klapper, W.; Pfortner, R.; Dührsen, U.; Eckstein, A.; Dürig, J.; Küppers, R. Recurrent mutations in NF-kappaB pathway components, KMT2D, and NOTCH1/2 in ocular adnexal MALT-type marginal zone lymphomas. Oncotarget 2016, 7, 62627-62639. [CrossRef]

79. Chanudet, E.; Huang, Y.; Ichimura, K.; Dong, G.; Hamoudi, R.A.; Radford, J.; Wotherspoon, A.C.; Isaacson, P.G.; Ferry, J.; Du, M.Q. A20 is targeted by promoter methylation, deletion and inactivating mutation in MALT lymphoma. Leukemia 2010, 24, 483-487. [CrossRef]

80. Jung, H.; Yoo, H.Y.; Lee, S.H.; Shin, S.; Kim, S.C.; Lee, S.; Joung, J.G.; Nam, J.Y.; Ryu, D.; Yun, J.W.; et al. The mutational landscape of ocular marginal zone lymphoma identifies frequent alterations in TNFAIP3 followed by mutations in TBL1XR1 and CREBBP Oncotarget 2017, 8, 17038-17049. [CrossRef]

81. Vela, V.; Juskevicius, D.; Dirnhofer, S.; Menter, T.; Tzankov, A. Mutational landscape of marginal zone B-cell lymphomas of various origin: Organotypic alterations and diagnostic potential for assignment of organ origin. Virchows Arch. 2021. [CrossRef] 
82. Behdad, A.; Zhou, X.Y.; Gao, J.; Raparia, K.; Dittman, D.; Green, S.J.; Qi, C.; Betz, B.; Bryar, P.; Chen, Q.; et al. High Frequency of MYD88 L265P Mutation in Primary Ocular Adnexal Marginal Zone Lymphoma and Its Clinicopathologic Correlation: A Study From a Single Institution. Arch. Pathol. Lab. Med. 2019, 143, 483-493. [CrossRef]

83. Cani, A.K.; Soliman, M.; Hovelson, D.H.; Liu, C.J.; McDaniel, A.S.; Haller, M.J.; Bratley, J.V.; Rahrig, S.E.; Li, Q.; Briceno, C.A.; et al. Comprehensive genomic profiling of orbital and ocular adnexal lymphomas identifies frequent alterations in MYD88 and chromatin modifiers: New routes to targeted therapies. Mod. Pathol. 2016, 29, 685-697. [CrossRef] [PubMed]

84. Yan, Q.; Wang, M.; Moody, S.; Xue, X.; Huang, Y.; Bi, Y.; Du, M.Q. Distinct involvement of NF-kappaB regulators by somatic mutation in ocular adnexal malt lymphoma. Br. J. Haematol. 2013, 160, 851-854. [CrossRef]

85. Moody, S.; Thompson, J.S.; Chuang, S.S.; Liu, H.; Raderer, M.; Vassiliou, G.; Wlodarska, I.; Wu, F.; Cogliatti, S.; Robson, A.; et al. Novel GPR34 and CCR6 mutation and distinct genetic profiles in MALT lymphomas of different sites. Haematologica 2018, 103, 1329-1336. [CrossRef] [PubMed]

86. Cascione, L.; Rinaldi, A.; Bruscaggin, A.; Tarantelli, C.; Arribas, A.J.; Kwee, I.; Pecciarini, L.; Mensah, A.A.; Spina, V.; Chung, E.Y.L.; et al. Novel insights into the genetics and epigenetics of MALT lymphoma unveiled by next generation sequencing analyses. Haematologica 2019, 104, e558-e561. [CrossRef]

87. Magistri, M.; Happ, L.E.; Ramdial, J.; Lu, X.; Stathias, V.; Kunkalla, K.; Agarwal, N.; Jiang, X.; Schürer, S.C.; Dubovy, S.R.; et al. The Genetic Landscape of Ocular Adnexa MALT Lymphoma Reveals Frequent Aberrations in NFAT and MEF2B Signaling Pathways. Cancer Res. Commun. 2021, 1, 1-16. [CrossRef]

88. Du, M.Q. MALT lymphoma: Many roads lead to nuclear factor-kappab activation. Histopathology 2011, 58, 26-38. [CrossRef]

89. Van Keimpema, M.; Gruneberg, L.J.; Mokry, M.; van Boxtel, R.; Koster, J.; Coffer, P.J.; Pals, S.T.; Spaargaren, M. FOXP1 directly represses transcription of proapoptotic genes and cooperates with NF-kappaB to promote survival of human B cells. Blood 2014, 124, 3431-3440. [CrossRef]

90. Clement, C.G.; Potluri, V.R.; Gonzales, J.; Qian, Y.W. Translocation (5; 11) in a conjunctival MALT lymphoma. Int. J. Clin. Exp. Pathol. 2011, 4, 722-726.

91. Kim, W.S.; Honma, K.; Karnan, S.; Tagawa, H.; Kim, Y.D.; Oh, Y.L.; Seto, M.; Ko, Y.H. Genome-wide array-based comparative genomic hybridization of ocular marginal zone B cell lymphoma: Comparison with pulmonary and nodal marginal zone B cell lymphoma. Genes Chromosomes Cancer 2007, 46, 776-783. [CrossRef]

92. Sasaki, Y.; Iwai, K. Roles of the NF-kappaB Pathway in B-Lymphocyte Biology. Curr. Top. Microbiol. Immunol. 2016, 393, 177-209. [CrossRef]

93. Liu, F.; Karube, K.; Kato, H.; Arita, K.; Yoshida, N.; Yamamoto, K.; Tsuzuki, S.; Kim, W.; Ko, Y.H.; Seto, M. Mutation analysis of NF-kappaB signal pathway-related genes in ocular MALT lymphoma. Int. J. Clin. Exp. Pathol. 2012, 5, 436-441.

94. Fabbri, G.; Rasi, S.; Rossi, D.; Trifonov, V.; Khiabanian, H.; Ma, J.; Grunn, A.; Fangazio, M.; Capello, D.; Monti, S.; et al. Analysis of the chronic lymphocytic leukemia coding genome: Role of NOTCH1 mutational activation. J. Exp. Med. 2011, 208, $1389-1401$. [CrossRef]

95. Kiel, M.J.; Velusamy, T.; Betz, B.L.; Zhao, L.; Weigelin, H.G.; Chiang, M.Y.; Huebner-Chan, D.R.; Bailey, N.G.; Yang, D.T.; Bhagat, G.; et al. Whole-genome sequencing identifies recurrent somatic NOTCH2 mutations in splenic marginal zone lymphoma. J. Exp. Med. 2012, 209, 1553-1565. [CrossRef] [PubMed]

96. Rossi, D.; Trifonov, V.; Fangazio, M.; Bruscaggin, A.; Rasi, S.; Spina, V.; Monti, S.; Vaisitti, T.; Arruga, F.; Fama, R.; et al. The coding genome of splenic marginal zone lymphoma: Activation of NOTCH2 and other pathways regulating marginal zone development. J. Exp. Med. 2012, 209, 1537-1551. [CrossRef]

97. Osipo, C.; Golde, T.E.; Osborne, B.A.; Miele, L.A. Off the beaten pathway: The complex cross talk between Notch and NF-kappaB Lab. Investig. 2008, 88, 11-17. [CrossRef] [PubMed]

98. Schwarzer, R.; Dorken, B.; Jundt, F. Notch is an essential upstream regulator of NF-kappaB and is relevant for survival of Hodgkin and Reed-Sternberg cells. Leukemia 2012, 26, 806-813. [CrossRef]

99. Wang, J.; Shelly, L.; Miele, L.; Boykins, R.; Norcross, M.A.; Guan, E. Human Notch-1 inhibits NF-kappa B activity in the nucleus through a direct interaction involving a novel domain. J. Immunol. 2001, 167, 289-295. [CrossRef]

100. De Decker, M.; Lavaert, M.; Roels, J.; Tilleman, L.; Vandekerckhove, B.; Leclercq, G.; Van Nieuwerburgh, F.; Van Vlierberghe, P.; Taghon, T. HES1 and HES4 have non-redundant roles downstream of Notch during early human T-cell development. Haematologica 2021, 106, 130-141. [CrossRef]

101. Morin, R.D.; Mendez-Lago, M.; Mungall, A.J.; Goya, R.; Mungall, K.L.; Corbett, R.D.; Johnson, N.A.; Severson, T.M.; Chiu, R.; Field, M.; et al. Frequent mutation of histone-modifying genes in non-Hodgkin lymphoma. Nature 2011, 476, 298-303. [CrossRef] [PubMed]

102. Zhang, J.; Dominguez-Sola, D.; Hussein, S.; Lee, J.E.; Holmes, A.B.; Bansal, M.; Vlasevska, S.; Mo, T.; Tang, H.; Basso, K.; et al. Disruption of KMT2D perturbs germinal center B cell development and promotes lymphomagenesis. Nat. Med. 2015, 21, 1190-1198. [CrossRef]

103. Fagan, R.J.; Dingwall, A.K. COMPASS Ascending: Emerging clues regarding the roles of MLL3/KMT2C and MLL2/KMT2D proteins in cancer. Cancer Lett. 2019, 458, 56-65. [CrossRef]

104. Perissi, V.; Aggarwal, A.; Glass, C.K.; Rose, D.W.; Rosenfeld, M.G. A corepressor/coactivator exchange complex required for transcriptional activation by nuclear receptors and other regulated transcription factors. Cell 2004, 116, 511-526. [CrossRef] 
105. Li, J.Y.; Daniels, G.; Wang, J.; Zhang, X. TBL1XR1 in physiological and pathological states. Am. J. Clin. Exp. Urol. 2015, 3, 13-23. [PubMed]

106. Venturutti, L.; Teater, M.; Zhai, A.; Chadburn, A.; Babiker, L.; Kim, D.; Beguelin, W.; Lee, T.C.; Kim, Y.; Chin, C.R.; et al. TBL1XR1 Mutations Drive Extranodal Lymphoma by Inducing a Pro-tumorigenic Memory Fate. Cell 2020, 182, 297-316.e227. [CrossRef] [PubMed]

107. Wang, X.; Xu, X.; Cai, W.; Bao, H.; Huang, H.; Liu, Y.; Yang, X.; Ruan, C.; Wu, D.; Shen, H.; et al. TBL1XR1 mutation predicts poor outcome in primary testicular diffuse large B-cell lymphoma patients. Biomark. Res. 2020, 8, 10. [CrossRef]

108. Jangam, D.; Sridhar, K.; Butzmann, A.; Samghabadi, P.; Plowey, E.D.; Ohgami, R.S. TBL1XR1 Mutations in Primary Marginal Zone Lymphomas of Ocular Adnexa are Associated with Unique Morphometric Phenotypes. Curr. Eye Res. 2020, 45, 1583-1589. [CrossRef]

109. O'Shea, J.J.; Holland, S.M.; Staudt, L.M. JAKs and STATs in immunity, immunodeficiency, and cancer. N. Engl. J. Med. 2013, 368, 161-170. [CrossRef]

110. Thurner, L.; Hartmann, S.; Neumann, F.; Hoth, M.; Stilgenbauer, S.; Küppers, R.; Preuss, K.D.; Bewarder, M. Role of Specific B-Cell Receptor Antigens in Lymphomagenesis. Front. Oncol. 2020, 10, 604685. [CrossRef]

111. Coupland, S.E.; Foss, H.D.; Anagnostopoulos, I.; Hummel, M.; Stein, H. Immunoglobulin VH gene expression among extranodal marginal zone B-cell lymphomas of the ocular adnexa. Investig. Ophthalmol. Vis. Sci. 1999, 40, 555-562.

112. Dagklis, A.; Ponzoni, M.; Govi, S.; Cangi, M.G.; Pasini, E.; Charlotte, F.; Vino, A.; Doglioni, C.; Davi, F.; Lossos, I.S.; et al. Immunoglobulin gene repertoire in ocular adnexal lymphomas: Hints on the nature of the antigenic stimulation. Leukemia 2012, 26, 814-821. [CrossRef]

113. Hara, Y.; Nakamura, N.; Kuze, T.; Hashimoto, Y.; Sasaki, Y.; Shirakawa, A.; Furuta, M.; Yago, K.; Kato, K.; Abe, M. Immunoglobulin heavy chain gene analysis of ocular adnexal extranodal marginal zone B-cell lymphoma. Investig. Ophthalmol. Vis. Sci. 2001, $42,2450-2457$.

114. Mannami, T.; Yoshino, T.; Oshima, K.; Takase, S.; Kondo, E.; Ohara, N.; Nakagawa, H.; Ohtsuki, H.; Harada, M.; Akagi, T. Clinical, histopathological, and immunogenetic analysis of ocular adnexal lymphoproliferative disorders: Characterization of malt lymphoma and reactive lymphoid hyperplasia. Mod. Pathol. 2001, 14, 641-649. [CrossRef]

115. Van Maldegem, F.; Wormhoudt, T.A.; Mulder, M.M.; Oud, M.E.; Schilder-Tol, E.; Musler, A.R.; Aten, J.; Saeed, P.; Kersten, M.J.; Pals, S.T.; et al. Chlamydia psittaci-negative ocular adnexal marginal zone B-cell lymphomas have biased VH4-34 immunoglobulin gene expression and proliferate in a distinct inflammatory environment. Leukemia 2012, 26, 1647-1653. [CrossRef] [PubMed]

116. Zhu, D.; Lossos, C.; Chapman-Fredricks, J.R.; Matthews, J.M.; Ikpatt, O.F.; Ruiz, P.; Lossos, I.S. Biased use of the IGHV4 family and evidence for antigen selection in Chlamydophila psittaci-negative ocular adnexal extranodal marginal zone lymphomas. PLoS ONE 2011, 6, e29114. [CrossRef] [PubMed]

117. Seifert, M.; Küppers, R. Human memory B cells. Leukemia 2016, 30, 2283-2292. [CrossRef] [PubMed]

118. Bahler, D.W.; Szankasi, P.; Kulkarni, S.; Tubbs, R.R.; Cook, J.R.; Swerdlow, S.H. Use of similar immunoglobulin VH gene segments by MALT lymphomas of the ocular adnexa. Mod. Pathol. 2009, 22, 833-838. [CrossRef] [PubMed]

119. Zhu, D.; Bhatt, S.; Lu, X.; Guo, F.; Veelken, H.; Hsu, D.K.; Liu, F.T.; Cubela, S.A.; Kunkalla, K.; Vega, F.; et al. Chlamydophila psittaci-negative ocular adnexal marginal zone lymphomas express self polyreactive B-cell receptors. Leukemia 2015, 29, 1587-1599. [CrossRef]

120. Arribas, A.J.; Bertoni, F. Methylation patterns in marginal zone lymphoma. Best Pract. Res. Clin. Haematol. 2017, 30, 24-31. [CrossRef]

121. Choung, H.K.; Kim, Y.A.; Lee, M.J.; Kim, N.; Khwarg, S.I. Multigene methylation analysis of ocular adnexal MALT lymphoma and their relationship to Chlamydophila psittaci infection and clinical characteristics in South Korea. Investig. Ophthalmol. Vis. Sci. 2012, 53, 1928-1935. [CrossRef]

122. Lee, M.J.; Min, B.J.; Choung, H.K.; Kim, N.; Kim, Y.A.; Khwarg, S.I. Genome-wide DNA methylation profiles according to Chlamydophila psittaci infection and the response to doxycycline treatment in ocular adnexal lymphoma. Mol. Vis. 2014, 20, 1037-1047.

123. Hother, C.; Rasmussen, P.K.; Joshi, T.; Reker, D.; Ralfkiaer, U.; Workman, C.T.; Heegaard, S.; Ralfkiaer, E.; Gronbaek, K. MicroRNA profiling in ocular adnexal lymphoma: A role for MYC and NFKB1 mediated dysregulation of microRNA expression in aggressive disease. Investig. Ophthalmol. Vis. Sci. 2013, 54, 5169-5175. [CrossRef] [PubMed]

124. Middle, S.; Coupland, S.E.; Taktak, A.; Kidgell, V.; Slupsky, J.R.; Pettitt, A.R.; Till, K.J. Immunohistochemical analysis indicates that the anatomical location of B-cell non-Hodgkin's lymphoma is determined by differentially expressed chemokine receptors, sphingosine-1-phosphate receptors and integrins. Exp. Hematol. Oncol. 2015, 4, 10. [CrossRef]

125. Kim, K.H.; Kim, T.M.; Go, H.; Kim, W.Y.; Jeon, Y.K.; Lee, S.H.; Kim, D.W.; Khwarg, S.I.; Kim, C.W.; Heo, D.S. Clinical significance of tumor-infiltrating FOXP3+ T cells in patients with ocular adnexal mucosa-associated lymphoid tissue lymphoma. Cancer Sci. 2011, 102, 1972-1976. [CrossRef]

126. Kinoshita, S.; Kase, S.; Ando, R.; Dong, Z.; Fukuhara, J.; Dong, Y.; Inafuku, S.; Noda, K.; Noda, M.; Kanda, A.; et al. Expression of vascular endothelial growth factor in human ocular adnexal lymphoma. Investig. Ophthalmol. Vis. Sci. 2014, 55, 3461-3467. [CrossRef] [PubMed]

127. Seifert, M.; Scholtysik, R.; Küppers, R. Origin and Pathogenesis of B Cell Lymphomas. Methods Mol. Biol. 2019, 1956, 1-33. [CrossRef] [PubMed] 
128. Küppers, R. Mechanisms of B-cell lymphoma pathogenesis. Nat. Rev. Cancer 2005, 5, 251-262. [CrossRef]

129. Krappmann, D.; Vincendeau, M. Mechanisms of NF-kappaB deregulation in lymphoid malignancies. Semin. Cancer Biol. 2016, 39, 3-14. [CrossRef] 